\title{
Literasi Konten Radikal di Media Online
}

\author{
Widodo Agus Setianto \\ Departemen Ilmu Komunikasi FISIPOL Universitas Gajah Mada \\ Pusat Studi Sosial Asia Tenggara (PSSAT)- UGM \\ Jl. Sosio Yustisia, Kampus UGM, Bulaksumur, Yogyakarta 55281 \\ Email: dodosetianto@gmail.com \\ Email: widas@gmail.com
}

\begin{abstract}
The outbreak of radical content in online media raises concerns. Efforts to minimize the negative effects of radical content in online media one of them is through literacy capabilities. This research tries to see the literacy ability of Islamic activist students in relation to radical content in online media. The research was conducted by using ethnography method toward 3 students of Islamic activist. The results showed that the informants have enough skills in media, especially in choosing, understanding and addressing online media that contain radical content. Informants respond moderately to radical content in relation to common life through respect, tolerance and acceptance of common life within the context of NKRI. This attitude is formed from a well-integrated social environment and moderate religious understanding.
\end{abstract}

Keywords: Online media, literacy, radical content, Islamic activist students

\begin{abstract}
Abstrak
Merebaknya konten radikal di media online menimbulkan keprihatinan banyak kalangan. Upaya meminimalisir pengaruh negatif konten radikal di media online salah satunya adalah melalui kemampuan literasi. Penelitian ini mencoba melihat kemampuan literasi mahasiswa aktifis Islam dalam kaitannya dengan koten radikal di media online. Penelitian dilakukan dengan menggunakan metode etnografi terhadap tiga mahasiswa aktifis Islam. Hasil penelitian menunjukkan bahwa para informan memiliki cukup ketrampilan dalam bermedia khususnya dalam memilih, memahami dan mensikapi media online yang memuat konten radikal. Informan menanggapi konten radikal secara moderat dalam relasinya dengan kehidupan bersama melalui sikap menghargai, toleransi dan menerima hidup bersama dalam konteks NKRI. Sikap ini terbentuk dari lingkungan sosial yang terintegrasi dengan baik dan pemahaman keagamaan yang moderat.
\end{abstract}

Kata kunci: Media online, literasi, konten radikal, mahasiswa aktifis Islam. 


\section{Pendahuluan}

Indonesia merupakan salah satu negara dengan laju pertumbuhan pengguna internet yang cukup tinggi. Data yang dilansir Internet World Stats akhir tahun 2016 mencapai 132.700.000 pengguna dari jumlah populasi penduduk 258.316.051 jiwa (http://www. internetworldstats. com/ top20.htm). Jumlah pengguna internet ini menempatkan Indonesia pada urutan ke 5 negara dengan jumlah pengguna internet terbesar di dunia setelah China, India, Amerika, dan Brazil.

Membaiknya infrastruktur jaringan serta mudahnya mendapatkan perangkat mobile dengan interkoneksitas tinggi dan harga terjangkau menjadi faktor yang sangat kontributif bagi pertumbuhan pengguna internet di Indonesia. Data survey APJII 2016 menunjukkan bahwa sekitar 67,2 juta orang atau 50,7 persen mengakses melalui perangkat genggam dan komputer; 63,1 juta orang atau 47,6 persen mengakses dari smartphone dan 2,2 juta orang atau 1,7 persen mengakses hanya dari komputer (Widiartanto dalam http://tekno. kompas.com). Jelas bahwa perangkat mobile menjadi faktor utama tingginya peningkatan jumlah pengguna internet di Indonesia.

Meningkatnya jumlah pengguna internet di Indonesia pada satu sisi menumbuhkan harapan besar akan semakin maju dan berkembangnya masyarakat Indonesia dari segi pemikiran karena terbukanya cakrawala pengetahuan sebagai akibat aliran informasi yang diterima. Selain itu akan semakin menumbuhkan daya kreatifitas bangsa Indonesia untuk mengembangkan dan membuat produk-produk yang lebih kreatif, inovatif dan kompetitif karena banyak contoh model yang dapat dikembangkan dan dapat disaingkan di pasar global sehingga dapat menopang pertumbuhan perekonomian nasional.

Aspek-aspek fungsional bersifat positif dari teknologi internet yang melahirkan media online ini menjadi harapan baru bagi tumbuhnya sebuah masyarakat yang lebih inklusif dalam kerangka memajukan kehidupan bersama yang lebih kondusif, damai dan toleran. Namun sebagaimana halnya sebuah teknologi yang diadopsi dalam kehidupan sosial, media online selain fungsional untuk tujuan-tujuan yang positif dapat juga bersifat disfungsional baik secara personal maupun secara sosial. Secara personal seseorang dapat menjadi tenggelam dalam keasyikan pencarian atau permainan di dunia maya sehingga terkungkung dalam lingkungan realitas simbolik yang subyektif dan egoistik. Sementara secara sosial menyebabkan seseorang menjadi abai terhadap waktu dan kewajiban-kewajiban hidup lainnya dalam kehidupan sosialnya.

Namun yang lebih mengkhawatirkan adalah internalisasi lingkungan realitas simbolik dunia maya ke dalam lingkungan realitas psikologis individu dan manifestasinya terhadap realitas empiris dalam kehidupan sosial. Satu hal yang tidak dapat dipungkiri sebagai hasil interaksi dari media online pada individu adalah pempribadian pengetahuan dan nilai-nilai simbolik dari realitas simbolik yang diperolehnya di media online. Pengetahuan dan nilai-nilai simbolik dari dunia maya dijadikan sebagai pengetahuan dan nilai-nilai pribadi yang akan memberikannya arah dan petunjuk perilaku tentang sesuatu yang diyakini sebagai benar dan salah. Sepanjang hal tersebut masih berada pada realitas psikologis individu dampaknya tentu hanya pada individu itu sendiri. Akan menjadi masalah apabila pengetahuan dan nilai-nilai hasil dari realitas simbolik tersebut diekspresikan dalam tindakan simbolik melalui media ataupun dalam bentuk tindakan sosial. Tentu hal ini akan menjadi permasalahan dalam kaitannya dengan ketertiban dan keamanan sosial.

Seiring dengan meningkatnya penetrasi internet dan pengguna internet dalam kurun waktu satu dekade terakhir, isu tentang radikalisme menjadi bingkai yang menghiasi konten pada laman-laman web maupun konten pada media-media sosial. Radikalisme disini bisa dalam pengertian pengetahuan, sikap dan tindakan yang cenderung radikal terkait dengan atau dalam menanggapi suatu 
keadaan, keyakinan, golongan, ataupun person. Radikalisme dalam hal keagamaan menjadi salah satu bagian penting yang mendasari, mewarnai dan mempengaruhi atmosfir bentuk-bentuk radikalisme lainnya. Radikalisme agama dapat menyasar pada keadaan, keyakinan, golongan atau person yang dianggap tidak sejalan dengan konstruksi pengetahuan, kepercayaan dan keyakinan seorang atau sekelompok orang sehingga perlu dilakukan tindakan perubahan yang ektrem atau radikal sesuai dengan nilainilai yang diyakininya.

Radikalisme terkait dengan masalah agama tidak dapat dipisahkan dari situasi ketidakberdayaan umat Islam baik di kancah internasional, nasional dan juga kondisi internal umat Islam Indonesia sendiri. Situasi internasional menempatkan Islam berada di bawah stigmatisasi negatif atas dominasi dan hegemoni Barat secara ideologi, politik dan militer. Secara nasional kondisi umat Islam Indonesia terpinggirkan secara politik, sosial dan ekonomi. Secara internal umat Islam Indonesia mengalami polarisasi di antara berbagai kelompok aliran dan organisasi. Aspirasi syariah umat Islam bagaikan menghadapi jalan buntu di tengah hiruk pikuk sekularisasi, kapitalisasi dan libelarisasi.

Kondisi ini menimbulkan perlawanan yang radikal terhadap dominasi Barat dengan munculnya organisasi seperti Al Qaeda yang dengan begitu cepat memunculkan sayapsayap perlawanan di berbagai wilayah negara dengan penduduk Islam. Pasca Al Qaeda muncul gerakan yang lebih radikal yakni Islamic State yang bukan hanya mampu mengundang jihadis dari berbagai negara di seluruh dunia untuk memperkuat kedudukannya di wilayah yang diklaimnya sebagai teritorinya, namun juga mampu menggerakkan aksi di berbagai wilayah lain termasuk di jantung-jantung pemerintahan negara-negara Barat.

Yang menarik adalah, aksi radikal dilakukan bukan hanya pada tataran empiris terkait dengan penerapan ideologi yang diyakini, akan tetapi juga ditransmisikan melalui internet yang ditampilkan di berbagai fitur baik melalui web, youtube, media sosial dan sebagainya sebagai konsumsi publik dunia. Propaganda dilakukan secara masif dan efektif melalui berbagai kanal di internet terkait dengan ideologi Islam dan kehidupan berbasis syariah Islam sebagai alternatif dari berbagai ideologi dunia khususya ideologi kapitalisme, sekularisme dan liberalisme yang dianggap sebagai paham yang menjauhkan manusia dari kehidupan yang sebenarnya menurut tuntunan agama dan sebagai biang ketidakadilan, penindasan, dan kehancuran dunia.

Dari berbagai pemberitaan dan laporan hasil penelitian menunjukkan bahwa propaganda ataupun penyebaran informasi menyangkut ideide radikal cukup efektif dalam menarik minat kaum muda Islam baik dalam tataran wacana, pemikiran, maupun tindakan. Dalam tataran wacana dan pemikiran dapat dilihat dinamikanya di media online, sedangkan dalam tataran tindakan terbukti pada beberapa kasus rekrutmen anggota kelompok radikal diperoleh melalui internet, demikian juga tindakan radikal seperti hijrah untuk ikut berperang dengan kelompok radikal, ataupun aksi-aksi penyerangan baik menggunakan senjata tajam, senjata api ataupun bahan peledak.

Kenyataan ini menunjukkan hal yang sangat memprihatinkan khususnya dalam konteks masyarakat Indonesia yang $87 \%$ penduduknya beragama Islam. Di tengah peringat tingkat literasi media yang rendah, yakni urutan 60 dari 61 negara berdasarkan pemeringkatan CCSU dalam News Release World's Most Literate Nations Ranked (http://webcapp. ccsu.edu/), penyebaran ide-ide radikal melalui media online menjadi sebuah ancaman bagi keberlangsungan keutuhan kehidupan bangsa Indonesia dan Negara Kesatuan Republik Indonesia (NKRI). Menjadi penting untuk mengetahui kemampuan literasi media di kalangan kaum muda Islam khususnya dari kalangan mahasiswa aktifis Islam terhadap konten radikal yang ada di media online.

Mahasiswa aktifis Islam merupakan 
entitas yang diasumsikan paling peduli dengan isu-isu ke-Islaman. Kalau mahasiswa aktifis Islam memiliki literasi yang baik, akan menjadi sebuah harapan yang baik bagi kelangsungan masa depan masyarakat dan bangsa Indonesia. Dengan demikian hasil penelitian ini secara khusus diharapkan dapat memberikan gambaran yang lebih rinci dan terpadu terkait dengan literasi mahasiswa aktifis Islam terhadap kontenkonten radikal di media online. Pengetahuan tentang literasi media online setidaknya akan memperkaya khasanah terkait dengan fakta empiris tentang literasi itu sendiri dan juga faktor-faktor yang secara ideosinkretik ikut mempengaruhi terbentuknya literasinya pada media. Oleh karenanya menarik untuk mempertanyakan bagaimana literasi mahasiswa aktifis Islam pada konten-konten radikal di media online.

Media online merupakan salah satu genre media yang berkembang jelang abad 21. Media online disebut juga dengan media digital yakni media yang tersaji secara online di internet, atau dalam bahasa Indonesia sering disebut dengan media "daring". Daring disini merupakan akronim dari "dalam jaringan". Jadi media "daring" maksudnya adalah media "dalam jaringan" internet (Kamus Besar Bahasa Indonesia).

Media online secara umum merujuk pada jenis atau format media yang hanya bisa diakses melalui internet baik berupa teks, foto, video, dan suara (Saputraa \& Nazimb, 2017). Dengan demikian semua platform media di media online seperti email, mailing list (milis), website termasuk di dalamnya portal berita, blog, WhatsApp, media sosial, tv online, radio online masuk dalam cakupan pengertian media online. Game, chat, kuis dan lain-lain juga termasuk dalam pengertian media online. Sedangkan secara khusus dalam konteks yang lebih spesifik, media online pengertiannya merujuk pada pengertian media massa dengan karakteristik tertentu yang menyajikan karya jurnalistik (baik berita, artikel, maupun feature) secara online (jurnalistik online-cyber journalism). Atau dengan kata lain media online adalah media massa yang tersaji secara online di situs web (website) internet terkait dengan karya jurnalistik (Romli, 2012).

Kehadiran internet dengan media online-nya membuat perubahan yang cukup revolusioner baik dari segi cara bermedia maupun dalam konteks kehidupan sosial masyarakat penggunanya. Orang tidak lagi harus mencari media dan duduk manis di suatu tempat untuk melihat dan mendengarkan sesuatu yang disajikan media. Saat ini media menjadi bagian yang melekat pada kehidupan setiap orang setiap saat. Media selalu mendampingi dimanapun seseorang itu berada. Sedangkan dalam konteks kehidupan sosial, telah banyak tulisan yang disajikan baik yang bersifat positif maupun negatif terkait dengan dampak media komunikasi online khususnya terhadap kehidupan sosial.

Terkait dengan konten di media online yang cukup menyita perhatian seiring dengan berbagaikejadian yang mengarah pada intoleransi dalam kehidupan masyarakat adalah masalah konten radikal yang melahirkan radikalisme dalam masyarakat. Radikal dan radikalisme, dua istilah yang akhir-akhir ini sering kali dikaitkan dengan aksi-aksi kekerasan yang dikonotasikan dengan kekerasan berbasis agama termasuk aksi terorisme (Yakin, 2015).

Kata radikal berasal dari bahasa Latin "radix" yang berarti akar. Yang dimaksud dalam pengertian ini adalah sesuatu yang mendasar atau sampai ke akar-akarnya. Kamus Besar Bahasa Indonesia mengartikan radikal sebagai "secara mendasar atau menyeluruh, amat keras menuntut perubahan, dan maju dalam berpikir atau bertindak". Sedangkan radikalisme, adalah faham politik kenegaraan yang menghendaki perubahan dan perombakan besar sebagai jalan untuk mencapai kemajuan (al-Barry 1994 : 648). Radikal dan radikalisme sesungguhnya dapat bermakna positif atau negatif. Tapi dalam konteks politik kontemporer global yang berimbas pada politik nasional, radikal dan radikalisme cenderung dipandang sebagai sesuatu yang bersifat negatif. Laughlin 
menyatakan ;" the words radical and radicalsm conjure up a number of images - attractive to some, repulsive to others: These are image of heroism and villainy, of hope and fear" (Lauglin 2012 : 8). Dalam konotasi maknanya yang negatif, radikal sama artinya dengan ekstrimisme, revolusioner, dan utopianism. Sedangkan dalam konotasi maknanya yang positif radikal sama artinya dengan kemajuan (progressivism), peduli lingkungan (ecologist), dan inovasi (innovation) (Lauglin $2012: 9-12$ ). Sikap otonom, independen dan non kooperatif juga dapat dikatakan sebagai suatu sikap yang radikal. Oleh karenanya sikapsikap yang kooperatif, kompromistis, dan moderat merupakan sikap-sikap yang dipandang tidak radikal.

Media online menjadi media yang sangat strategis dalam menyemaikan ide-ide radikal. Media online telah lama digunakan sebagai sarana indroktinasi dan rekrutmen para jihadis. Website merupakan platform dalam media online yang paling banyak digunakan. Jeremy White (2012) menuliskan website jihad berkembang sangat pesat, dari sekitar 100 website jihad pada dekade 2000 menjadi sekitar 4.800 website pada tahun 2012. Website ini pada umumnya bersifat interaktif untuk memberikan penjelasan kepada pengunjung. Ada empat kategori bentuk website yang diidentifikasi, di antaranya adalah 1) Directories of Links to External Sites, 2) Mailing List and Message Boards, 3) Noninteractive Homepages of Sympathizers, 4) Mother Sites (White 2012). Website ini biasanya difungsikan untuk 1) Issuing Statements, 2) Communication and Planning, 3) Training, 4) Recruitment, 5) Propaganda (Dave 2016). Dengan berkembangnya platform di media online, sarana penyebaran paham-paham radikal menjadi semakin beragam.

Dalam menangkal pemahaman negatif terkait konten radikal di media online, kemampuan literasi bermedia menjadi sangat penting. Potter mengemukakan : "media massa memiliki potensi memberi banyak efek negatif pada individu; literasi media diperlukan untuk membantu orang melindungi diri dari efek yang berpotensi negatif'(Potter 2010). Kemampuan literasi akan mampu meningkatkan pemahaman tehadap isi media dan memperkuat kontrol individu terhadap media. Pemahaman dan kontrol terhadap isi media bukan hanya kemampuan dalam mengidentifikasi dan membedakan antara informasi fakta atau fiksi, namun juga kemampuan untuk mengidentifikasi dan membedakan website dengan sumber terpercaya dan website yang tidak bertanggungjawab. Hal ini setidaknya sejalan dengan definisi literasi media sebagaimana dikemukakan oleh Aufderheide \& Firestone ; "Literacy is the ability to access, analyze, evaluate and communicate messages in a variety of forms" (Hobbs \& Frost 2003): Yang perlu ditambahkan terkait dengan elemen definisi literasi media ini adalah pemahaman sumber dan dampak dari pesan tersebut (Rubin 1998). Silverblatt mengidentifikasi lima elemen literasi media ; "awareness of the impact of media on the individual and society, understanding of the process of mass communication, development of strategies with which to analyze and discuss media message, awareness of media content as a text that provide insight into our contemporary culture and ourselves, cultivation of an enhanced enjoyment, understanding, and aprpreciation of media content" (Baran/Davis 2015; Lipschultz 2015; Sharpe 2014).

Secara garis besar kemampuan literasi media dapat dibedakan dalam dua komponen pokok, yakni skill atau ketrampilan yang berupa ketrampilan dasar dan ketrampilan lanjut, serta struktur pengetahuan yang terdiri dari real world dan simulated media world (Potter 2011). Real world yang dimaksudkan disini adalah dunia nyata atau dunia empiris yang merupakan kehidupan sehari-hari yang nyata dalam berinteraksi di tengah-tengah kehidupan masyarakat. Sedangkan simulated media world adalah dunia yang merupakan bentukkan atau konstruksi dari media. Ini merupakan realitas media yang bersifat simbolik, bukan realitas empiris yang menggambarkan dunia nyata yang sesungguhnya. Dalam banyak kasus, realitas media ini sering menjadi seperti lingkungan 
pengganti dari dunia nyata yang seolah-olah merupakan representasi dari dunia nyata. Padahal ini merupakan simulacra, realitas simulative yang dibentuk berdasarkan kepentingan, nilai, ideologi, juga konteks ekonomi, politik, sosial dan budaya. Dalam konteks inilah literasi media diperlukan.

\section{Metode Penelitian}

Penelitian ini mencoba melihat perilaku dalam berinteraksi dengan media online terkait konten radikal. Paradigma penelitian yang digunakan adalah paradigma konstruktivisme, dengan jenis dan pendekatan penelitian bersifat deskriptif kualitatif. Metode yang digunakan adalah metode etnografi "as a method rooted in the social anthropological tradition, concerned with how social realities are seen from the perspective of those who live and work in them" (Daymon \& Holloway, 2011). Hammersley menyampaikan tiga prinsip dasar metodologis penelitian etnografi, pertama adalah naturalisme, yaitu bersifat alami bukan dalam latar buatan yang secara spesifik dibuat untuk tujuan penelitian. Kedua adalah pemahaman, yaitu prinsip yang mempelajari karakter subjek penelitian sebelum menjelaskan perilakunya. Ketiga adalah penemuan, yakni konsepsi proses penelitian sebagai induktif atau berdasarkan temuan (Genzuk, 2005). Etnografi merupakan suatu bentuk penelitian yang berfokus pada makna sosiologi melalui observasi lapangan dari fenomena sosiokultural. Penelitian ini membutuhkan observasi partisipatoris peneliti dan deskripsi tertulis (Emzir, 2008).

Data diperoleh dari informan teramati yang merupakan mahasiswa aktifis Islam yang tinggal di Masjid Griya Perwita Darussalam, Sukoharjo, Ngaglik, Sleman. Selain melakukan wawancara, data juga diperoleh melalui observasi dalam keseharian hidup mereka khususnya dalam interaksinya dengan media online. Data-data dikumpulkan selama tiga bulan dengan membuat catatan-catatan rinci, diseleksi, dikategorisasi dan dibuatkan inferensinya sebagai kesimpulan logis atas temuan yang ada.

\section{Hasil Penelitian dan Pembahasan Latar Belakang dan Lingkungan Sosial Informan}

Fahmi, Faidz, dan Rio merupakan tiga orang mahasiswa aktifis Islam dari delapan mahasiswa yang tinggal di Masjid Darussalam Griya Perwita Wisata yang menjadi subyek pengamatan dalam penelitian ini. Fahmi berasal dari Rengat Indragiri Hulu Provinsi Riau, Faidz berasal daerah Wanareja Cilacap Jawa Tengah, dan Rio berasal dari Bandar Lampung. Ketiganya merupakan mahasiswa dari perguruan tinggi yang sama, yakni sebuah universitas Islam di Yogya Utara. Fahmi adalah mahasiswa Jurusan Teknik Sipil angakatan tahun 2013, Faidz adalah mahasiswa Jurusan Ekonomi Syariah Fakultas Ekonomi angkatan 2010, sedangkan Rio mahasiswa Jurusan Hukum Islam Fakultas Ilmu Agama angkatan tahun 2014.

Fahmi merupakan anak ke tiga dari tiga bersaudara dari pasangan suami istri yang bekerja sebagai aparatur sipil negara. Ayahnya pegawai di Dinas Kesehatan Kabupaten Indragiri Hulu, sedangkan ibunya pegawai di sebuah rumah sakit pemerintah. Sebagaimana dengan kebanyakan orang Sumatra khususnya etnik Melayu yang identik dengan Islam, Fahmi dibesarkan dalam lingkungan keluarga yang taat dalam menjalankan perintah agama. Bapak dan ibunya merupakan sosok yang saleh yang menegakkan sholat lima waktu, puasa di bulan Ramadhan, menunaikan zakat, membaca al Quran, dan aktif mengikuti pengajian yang di selenggarakan di lingkungan masjid kampungnya. Orang tuanya selalu mengajak Fahmi dan saudarasaudara lainnya sholat berjamaah di masjid, dan membiasakan untuk membaca al Quran pada waktu-waktu tertentu di rumah.

Orang tuanya sangat menekankan pada anak-anak dan keluarganya untuk menjaga adab, khususnya dengan adab kepada orang yang lebih tua, dan mengajarkan untuk selalu menyapa dan tersenyum pada siapapun. Fahmi dan keluarganya kebetulan tiggal di lingkungan yang juga banyak penduduk yang berasal dari warga 
negara keturunan khususnya warga keturunan Cina. Ketika SMA, teman-teman Fahmi juga banyak yang merupakan anak dari keturunan Cina. Dalam lingkungan tempat tinggal yang multikultur semacam ini, orang tuanya mengajarkan agar selalu menjaga hubungan baik dengan siapapun, bersikap toleran dalam masalah kemasyarakatan, dan terkait dengan masalah akidah agar tetap dijaga dengan tidak mencela akidah dari teman atau tetangga yang berkeyakinan berbeda.

Fahmi tinggal di Yogya sejak tahun 2013 saat diterima sebagai mahasiswa dan tinggal di masjid Darussalam mengikuti kakaknya yang juga kuliah di universitas yang sama. Selain kuliah, keseharian Fahmi adalah sebagai pengurus Masjid Darussalam dengan posisi sekretaris. Selain sebagai sekretaris fahmi juga membimbing dan mengajarkan tahsin atau membaca al-Quran kepada bapak-babak dan ibu-ibu, juga pemuda kompleks dan mahasiswa yang menjadi yuniornya yang mendatanginya di masjid Darussalam. Membimbing tadarus terkhusus pada hari Jumat yakni pembacaan surat Al Kahfi, membacakan hadist-hadis dan syarah hadist khususnya dari kitab Riyadhlus Sholihin, dan membimbing Taman Pendidikan Al Quran (TPA) untuk anak-anak, mengimami sholat, memberikan tausiah, menghafalkan al Quran, dan juga mengikuti pengajian-pengajian yang diselenggarakan di masjid.

Selama kuliah Fahmi aktif dalam kegiatan kemahasiswaan khususnya sebagai mualim atau pemandu pesantren kampus untuk mahasiswa baru. Fahmi juga aktif sebagai pemandu dalam Latihan Kepemimpinan Islam Dasar dan Orientasi Nilai Dasar Islam di kampusnya. Selain aktif dalam kegiatan kemahasiswaan Fahmi Hamdani juga aktif berdiskusi dengan sesama teman mahasiswa khususnya terkait dengan adab terhadap orang tua, masalah perbedaan agama, masalah-masalah politik, kelompok-kelompok pemikiran dalam Islam seperti sekulerisme, pluralisme dan liberalisme (sepilis) dan ahlussunah wal jamaah.

Faidz merupakan anak ke enam dari sepuluh bersaudara. Datang ke Yogya tahun 2010 ketika diterima masuk di perguruan tinggi. Tinggal di Masjid Darussalam sejak tahun 2011 menjabat sebagai bendahara masjid dalam ketakmiran. Sama halnya dengan Fahmi, Faidz juga membantu bapak-bapak dan ibu-ibu belajar membaca al Quran, juga membacakan hadisthadist bakda sholat Subuh dan sesekali membantu sebagai pengajar TPA, dan mengimami sholat. Selain aktif mengikuti kajian-kajian keagamaan, Faidz juga mengajar ngaji di Pondok Pesantren Hidayatullah.

Wanareja merupakan sebuah desa di Kecamatan Wanareja Kabupaten Cilacap. Di sinilah Faidz menghabiskan masa kecilnya bersama dengan 9 saudara lainnya. Bapak dan ibunya meski berpofesi sebagai wiraswastawan dalam hal ini adalah pedagang, tidak lupa akan pendidikan anak-anaknya, tak terkecuali pendidikan agama. Sejak kecil anak-anaknya didik untuk taat dalam menjalankan perintah agama, khususnya sholat lima waktu dan mengaji kitab suci. Hal ini tentu sangat dipengaruhi oleh lingkungan dimana Faidz tinggal yang merupakan komunitas masyarakat yang kental dengan nuansa Islam tradisional yakni komunitas masyarakat Nahdlatul Ulama (NU). Meski mayoritas berpenduduk Islam, banyak warga non muslim yang tinggal dan menjadi warga di daerah itu. Tradisi keagamaan NU yang toleran membuat anggota masyarakat non muslim merasa menjadi bagian dari masyarakat setempat dengan segala tradisinya. Hal ini terlihat manakala ada seorang non muslim meninggal, anggota keluarganya juga menyelenggarakan kenduren sebagaimana kebiasaan warga Nahdliyin apabila ada anggota keluarganya meninggal. Faidz bersama dengan tetangga lainnya ikut bertakziah dan ikut pada acara selamatan yang diselenggarakan untuk 3 hari, 7 hari dan 40 hari kematian.

Saat SMP Faidz berpisah dengan orang tuanya mengikuti pendidikan pondok pesantren tradisional Nahdlatul Ulama di daerah Sumpiuh. Hal ini berlanjut hingga pendidikan menengah atas, dimana Faidz mengambil sekolah kejuruan di pondok pesantren yang sama. Di Sumpiuh, 
Faidz tidak hanya menimba ilmu-ilmu umum sebagai bekal keahlian hidup, akan tetapi juga menimba ilmu-ilmu agama sebagai penuntun hidup. Demikianlah ilmu agama dipelajari melalui proses yang panjang di pondok pesantren selama enam tahun hingga kemudian selesai, dan Faidz memutuskan untuk melanjutkan kuliah di Yogya dengan mengambil jurusan Ilmu Ekonomi. Selama menjadi mahasiswa, Faidz tidak menjadi anggota dari organisasi kemahasiswaan tertentu. Namun Faidz aktif dalam berbagai kegiatan kampus khususnya yang terkait dengan kegiatan ke-Islaman. Minatnya adalah pada masalah dakwah Islam, oleh karenanya dalam kegiatan kemahasiswaan lebih memilih pada kehidupan dakwah dengan menjadi anggota lembaga dakwah kampus yang fokus kegiatannya pada pembinaan dakwah mahasiswa baru. Faidz aktif dalam kegiatan Latihan Kepemimpinan Islam, Komunitas AlQuran UII, dan sebagai mualim pesantren di kampusnya. Meski aktif dalam kegiatan ke-Islaman, Faidz tidak suka pada pengelompokkan keagamaan, oleh karenanya dia tidak mengikuti kelompok keagamaan tertentu. Faidz juga tidak suka membicarakan masalah politik terkait umat Islam, fokusnya adalah hanya pada dakwah Islam. Tetapi dalam diskusi dengan kelompok-kelompok yang berpikiran liberal terhadap Islam, Faidz berupaya mengembalikannya pada landasan hukum Islam yakni Quran dan hadist. Semasa menjadi mahasiswa Faidz sempat juga berwiraswata selama satu tahun. Meski telah lulus pada tahun 2016 lalu, Faidz masih tetap tinggal di Masjid Darussalam sambil mengisi hari-harinya dengan berkerja di Pondok Pesantren Hidayatullah.

Rio merupakan anak bungsu dari empat bersaudara. Tinggal di Masjid Darussalam sejak tahun 2014 saat diterima sebagai mahasiswa dan menjabat sebagai bendahara masjid dalam ketakmiran menggantikan posisi Faidz. Aktifitas harian Rio selain kuliah, menjalani kehidupan rutinnya di masjid Darussalam yakni mengurus keperluan masjid, mengajarkan membaca al Quran, mengajar TPA, membacakan syarah hadist, mengimami sholat, sesekali sebagai khatib sholat Jumat, memimpin pembacaan surat al Kahfi pada Jumat bakda subuh, memberi les privat baca al Quran dengan mendatangi rumah penduduk, menghafalkan al Quran, dan aktif mengikuti kajian-kajian keagamaan.

Rio berasal dari lingkungan keluarga guru. Bapaknya seorang guru SMA sedangkan ibunya seorang guru SMP. Sebagai anak dari orang tua yang berlatar belakang guru, pendidikan merupakan suatu hal yang sangat ditekankan. Bukan hanya pada pendidikan umum, namun juga pendidikan agama. Ibunya seorang mualaf, namun sangat menekankan pentingnya belajar agama. Bapaknya sangat mendorong untuk aktif dalam kegiatan keagamaan di kampung tempatnya tinggal. Bapak dan ibunya merupakan jemaah aktif di masjid. Bahkan bapaknya menekankan kepada keluarganya untuk selalu menjalankan sholat wajib di masjid. Selain itu bapak dan ibunya juga sangat menekankan pada masalah adab dan akhlak kepada anak-anaknya. Adab dan akhlak ini diterapkan bukan hanya di lingkungan keluarga, namun juga di lingkungan tempat tinggal mereka khususnya kepada para tetangga baik yang muslim maupun non muslim.

Ketika lulus SMA tahun 2014, Rio memilih melanjutkan kuliah di Yogya dan mendaftar pada jurusan hukum Islam. Keputusannya memilih jurusan Hukum Islam karena memang ingin lebih mendalami lebih jauh tentang Islam khususnya yang menyangkut aspek hukumnya. Hukum Islam menarik perhatiannya karena negeri yang mayoritas penduduknya muslim seperti Indonesia sistem hukumnya bukan mengedepankan hukum Islam. Hal ini menarik untuk didalami bagaimana sebenarnya hukum Islam itu sehingga tidak bisa diterapkan secara penuh di Indonesia yang berpenduduk mayoritas umat Islam.

Rio bukanlah tipikal mahasiswa yang aktif dalam kegiatan kemahasiswaan. Di kampus dia tidak mengikuti kegiatan kemahasiswaan apapun sebagaimana Fahmi dan Faidz. Di kampus aktifitas sepenuhnya hanyalah kuliah. Namun demikian, Rio memiliki kegiatan keagamaan di luar kampus. Di Masjid Darussalam dimana 
Rio tinggal sejak tahun 2014, Rio mengajar dan membina anak-anak belajar membaca Al Quran sekaligus mengurus TPA yang ada. Selain itu juga mendampingi ustadz dalam memberikan kajian di berbagai tempat.

\section{Lingkungan dan Ketrampilan Media}

Fahmi mulai bersentuhan dengan internet saat kelas 1 SMP. Di sekolahnya setiap siswa mendapatkan pelajaran dalam mengoperasikan atau menggunakan internet. Semula internet hanya digunakan untuk mencari bahan dalam mengerjakan tugas yang diberikan guru di sekolah. Pelajaran menggunakan internet di sekolah memang ditujukan untuk memudahkan siswa dalam mencari bahan-bahan penunjang pelajaran. Seiring perjalanan waktu, ketrampilan menggunakan internet ini berkembang, penggunaan internet tidak lagi hanya untuk mencari bahan dalam menyelesaikan tugas sekolah, akan tetapi juga untuk kepentingankepentingan lainnya seperti berkomunikasi melalui sosial media, melihat portal berita, you tube, artikel-artikel di blog, juga untuk belanja online dan bermain game.

Melalui internet inilah Fahmi berkomunikasi dan melakukan aktualisasi diri. Fahmi Hamdani setidaknya memiliki delapan sarana berkomunikasi via internet, di antaranya adalah facebook, twitter, instagram, line, gmail, yahoo, messanger, WhatsAap dan BBM. Semua sarana komunikasi ini digunakan selain untuk berkomunikasi, juga digunakan sebagai sarana dakwah dan update berita yang dianggap bermanfaat bagi siapapun yang terhubung dengannya. Baginya sarana komunikasi ini adalah sarana untuk menyebarkan kebaikan yang merupakan amal baik yang dapat dilakukannya.

Dalam waktu senggangnya, internet juga digunakan untuk bermain game online. Game online yang disukainya adalah yang terkait dengan petualangan dan perang-perangan. Selain itu juga untuk membuka portal berita. Portal berita yang sering diaksesnya adalah portal berita yang bersifat umum, agama ataupun portal berita kampus yakni Unisia. Portal berita agama yang sering diaksesnya adalah Islam Pos.Com, Era Muslim.Com, muslim.or.id. Sedangkan untuk youtube, video agama yang sering diakses adalah youtube Ustadz Khalid basalamah, Hanan Ataki, Zainudin MZ, Zakir Naiq, Ahmad Dedad, dan Aa Gym atau Abdullah Gymnastiar.

Dalam memenuhi kebutuhannya melalui internet, tak kurang 6 jam sehari Fahmi berinteraksi dengan internet. Waktu ini akan terus bertambah apabila juga dimasukkan keperluan lainnya seperti mencari bahan untuk menyelesaikan tugas-tugas kuliah atau menonton youtube yang bisa memakan waktu hingga 9 sampai 10 jam. Fahmi mengakses internet biasanya melalui handphone dan juga laptop.

Faidz mengenal internet saat sekolah di Sekolah Kejuruan di Pondok Pesantren tempat dia menimba ilmu agama di daerah Sumpiuh, tepatnya saat kelas dua SMK dimana internet menjadi salah satu ketrampilan yang diajarkan di sekolahnya. Faidz lebih banyak menggunakan internet untuk bersosial media, membuka portal berita dan menonton video youtube. Di antara media interaksi yang digunakan adalah facebook, BBM, WhatsAap, gmail, line dan instagram. Media-media ini digunakannya sebagai media untuk menyebarkan kebaikan dan pengetahuan tentang Islam, selain juga untuk berkomunikasi secara pribadi. Faidz tidak suka pada game online, dia lebih suka pada game offline. Youtube digunakannya juga untuk mendapatkan pengetahuan agama dari ustadz-ustadz yang dianggapnya moderat. Sedangkan portal berita yang sering diaksesnya adalah salingsapa.com, beritaumatislam.com yang didapatkannya dari download aplikasi. Selain juga portal-portal umum, dan portal kampus yakni Unisis. Faidz menggunakan waktunya untuk berinteraksi dengan internet hanya seperlunya saja manakala ada waktu senggang. Rata-rata perhari untuk mengakses internet sekitar 4 jam yang diaksesnya melalui handphone dan laptop.

Berbeda dengan Fahmi dan Faidz, Rio mengetahui dan belajar internet bukan dari hasil pendidikan formal di sekolah, melainkan belajar dari seorang temannya saat 
kelas satu SMP. Sosial media, game online, portal berita dan web merupakan bagian dari kegiatannya dalam berinteraksi dengan internet. Media sosial yang digunakannya antara lain adalah facebook, instagram, skip, WhatsAap, goodwrite, path, salingsapa dari muslim.com serta twiter. Media ini juga digunakannya selain untuk update status terkait masalah agama atau kutipan pesan-pesan alquran dan hadist, juga kepentingan penyampaian acara kajian yang diikutinya. Rio senang bermain game online terkait dengan perang-perangan, pointblak atau tembak-tembakan, dan juga crazycard. Portal berita yang bisa digunakan sebagai rujukan penambah pengetahuannya adalah Islam Pos.Com, Era Muslim.Com, muslim.or.id., republika, Hidayatullah, IslamPos, Islam medis, dan muslim.or.id. Rio menghabiskan waktunya di depan internet sekitar 4 sampai dengan 5 jam perhari. Akses internet dilakukannya melalui handphone, laptop dan terkadang juga dari warung internet.

\section{Pemahaman atas Konten Media}

Fahmi seorang yang selektif dalam bermedia. Meski banyak platform media yang dimiliki, Fahmi tidak serta merta mengambilnya begitu saja. Media ataupun konten media yang dinilainya tidak kredibel, provokatif, memecahbelah umat, menyebar berita bohong dan fitnah, atau cenderung radikal, akan dilewatinya begitu saja. Pengetahuan agama dan nilai-nilai kemasyarakatan yang diserapnya secara otomatis menolak media yang menyebarkan konten sebagaimana disebutkan di atas. Kalaupun terpaksa tidak dapat menghindar, Fahmi membacanya hanya sebagai pengetahuan terkait dengan entitas dan pemahaman yang berada di luar dirinya. Untuk hal-hal yang membuatnya bimbang, Fahmi tidak segan untuk mendiskusikan dengan ustadz yang dianggapnya paham dengan masalah-masalah tersebut. Berbagai informasi yang diperoleh Fahmi melalui tulisan atau berita-berita di media online baik melalui link dalam media sosial, portal berita maupun web, membawa Fahmi pada kesimpulan bahwa secara keseluruhan kondisi umat Islam di Indonesia semakin membaik. Indikasi ini diperolehnya dengan semakin banyaknya portal atau web yang menyajikan konten terkait dengan agama Islam, demikian juga pengajian-pengajian dari ustadz-ustadz terkenal yang diupload melalui youtube. Selain jumlahnya semakin banyak dan beragam, jejak dari para warga net yang melihat dan melike juga semakin banyak. Kualitas penyaji materi dan materi yang disampaikan juga semakin berkelas dilandaskan pada kitab-kitab yang dapat dirujuk dan dipertanggungjawabkan.

Even pemilihan Gubernur dalam Pilkada DKI yang begitu ramai diberitakan di berbagai media tak terkecuali juga di media online menjadi semacam petunjuk bahwa umat Islam semakin sadar akan agamanya dan bersatu untuk membela agamanya. Dengan berbagai peristiwa yang menyatukan umat Islam, dalam pandangan Fahmi, Islam akan menjadi lebih baik lagi khususnya dalam peran kemasyarakatannya. Tapi terkait dengan konten bernada provokatif dan memecah belah yang mengkafirkan dan tidak akan mensholatkan umat Islam karena perbedaan masalah politik dalam kasus pilkada DKI, Fahmi sangat tidak setuju, karena ini bukan akhlak Islam. Fahmi lebih melihat masalah ini sebagai upaya provokasi dalam menyudutkan Islam, umat Islam dan citra Islam. Hal ini dapat menimbulkan stigmatisasi negatif terhadap Islam, sebagai akibat dari ketidak tahuan atau kurangnya ilmu, juga karena sikap dan perilaku dari umat Islam sendiri yang cenderung tidak simpatik dan menimbulkan sikap antipati. Oleh karenanya Fahmi memandang perlu adanya pencegahan berupa pemahaman yang benar tentang islam, dan harus ada keseimbangan terkait dengan berbagai konten terkait Islam di media online khususnya media sosial.

Masalah khilafah sebagai wacana dalam media online, Fahmi menganggapnya bukan sebagai konten radikal. Akan tetapi kalau konten tersebut mempengaruhi dan mengarahkan orang untuk bertindak menegakkan khilafah dengan membenturkannya pada sistem yang tengah 
berjalan sekarang, Fahmi tidak sependapat. Hal ini akan membuat Islam menjadi semakin tersudut. Betapapun khilafah Islamiyah merupakan nubuat dan merupakan bagian dari ajaran agama Islam yang harus diyakini. Namun menegakkan khalifah Islam di Indonesia sebagaimana HTI meski tanpa kekerasan akan menimbulkan perlawanan yang dapat menghancurkan Islam itu sendiri. Indonesia telah memiliki sistem ideologi dan ketata negaraan berupa Pancasila, UUD 45 dan NKRI yang telah menjadi kesepakatan bersama. Sehingga tidak pada tempatnya harus dibenturkan dengan khilafah. Kalaupun setuju dengan adanya negara khilafah Islam, tentu bukan yang diperjuangkan oleh HTI, akan tetapi apa yang dijanjikan dengan adanya Imam Mahdi dan Isa Al Masih di akhir zaman nanti. Sehingga belum saatnya khilafah ditegakkan melalui HTI.

Demikian pula halnya dengan ISIS yang memperjuangkan khilafah dengan kekerasan, Fahmi sangat menentang metode yang digunakan oleh ISIS. Baginya apa yang dilakukan ISIS dalam mengakkan khilafah bukanlah sebagai ajaran Islam karena Islam tidak mengajarkan jalan kekerasan. Islam adalah agama yang lebih mengutamakan kedamaian dan kemashlahatan bagi umatnya. Pada dasarnya Fahmi tidak setuju dengan cara-cara radikal dalam memperjuangkan Islam dan nilai-nilai Islam.

Sebagai aktifis dakwah kampus, Faidz hanya mengakses konten-konten media online yang mengajak pada orang untuk belajar ilmu agama dan mengimplementasikan dalam kehidupan dengan baik. Hal ini dapat dilihat dari web atau portal berita yang diaksesnya, semua representasi dari web atau portal berita moderat yang menekankan pada kesejahteraan hidup bersama. Meski konten berbau radikal tidak menarik perhatian Faidz, namun Faidz tetap mengikuti berbagai informasi terkait dengan konstelasi politik umat Islam. Kasus penistaan agama (Ahok), HTI dan ISIS merupakan berita di media online yang tidak luput dari perhatiannya. Dalam kasus Ahok, Faidz murni melihatnya sebagai kasus penistaan agama. Faidz tidak setuju terhadap politisasi kasus penistaan agama ini yang melahirkan berbagai gerakan bela Islam melalui aksi-aksi demonstrasinya. Dalam pemahaman Faidz ini justru memperlihatkan kelemahan umat Islam yang seolah menampakan umat Islam bersatu dalam kasus ini, namun sesungguhnya terbelah, karena tidak semua umat Islam berada dalam satu kutub yang sama. Belum lagi berbagai persoalan kecil yang tidak substantif dan tidak prinsipil dalam aspek cabang Islam yang diperdebatkan baik di media sosial mapun tulisan-tulisan dalam blog dan juga portal-portal Islam yang lebih menekankan kebenaran pada apa yang menjadi pandangannya dan menyalahkan bahkan mencela pihak yang lain. Oleh karenanya Faidz tidak suka pada pemaksaan melalui tafsir terhadap kebenaran yang menyudutkan pihak lain dan mengancam pihak lain seperti haram menshalatkan pihak yang berbeda dalam dukungan politik, padahal samasama beragama Islam. Dengan kondisi yang demikian itu, sulit bagi Islam untuk berkembang dalam misinya sebagai rahmatan lil'alamin. Hal tersebut juga mencerminkan betapa pengetahuan tentang ke-Islaman di antara banyak warga Indonesia yang beragama Islam yang direpresentasikan melalui media online masih jauh dari yang diharapkan. Dari pengamatannya terhadap akhlak kaum muslim yang berinteraksi melalui media online khususnya di media sosial, seperti mencerminkan tingkat pendidikan formal yang masih kurang, karena kata-kata yang digunakan tidak mencerminkan orang-orang yang berpendidikan.

Khilafah memang merupakan ajaran Islam sebagaimana dinubuatkan Rasul, oleh karenanya tidak ada alasan bagi Faidz untuk tidak menerima ajaran tentang khilafah. Namun apa yang dilakukan oleh Hizbut Thahrir dan ISIS terkait dengan perjuangan menegakkan khilafah Islamiyah baginya adalah sebagai upaya penipuan umat, karena apa yang dilakukan masih jauh dari tanda-tanda nubuat yang disampaikan oleh Rasul. Menolak Pancasila dan ingin menggantikannya dengan khilafah untuk saat ini termasuk dalam kategori tindakan radikal dan dapat merugikan 
umat Islam. Oleh karenanya Faidz sangat tidak mendukung dengan apa yang dilakukan oleh Hizbut Thahrir. Apalagi terkait dengan ISIS yang dalam berbagai informasi yang diperolehnya melalui media online cenderung brutal dengan metode kekerasan, bahkan kekejian yang di luar rasa prikemanusiaan yang sama sekali jauh dari ajaran Islam..

Faidz lebih menekankan pada persiapan untuk menyambut datangnya khilafah melalui pendidikan dan dakwah. Karena dengan pendidikan dan dakwah akan memperluas pengetahuan tentang agama sehingga dapat memahami tanda-tanda akan datangnya khilafah yang sesungguhnya sebagaimana dinubuatkan oleh Rasul. Dalam menyampaikan aspirasi khilafah kelak kalau memang sudah saatnya, Faidz menyatakan bahwa demo tidak diperlukan. Kalaupun harus dilakukan itu merupakan jalan atau pilihan terakhir. Pun demikian kalau harus menggunakan kekerasan dalam pengertian perang mempertahankan keyakinan, itu juga merupakan jalan terakhir.

Rio melihat gambaran yang cukup menarik terkait dengan fenomena Islam di Indonesia melalui media online yang diaksesnya. Media online dengan berbagai web blog, maupun portal-portal Islam memberi konstribusi dalam persatuan umat Islam. Masifnya pemberitaan dan ulasan tentang ke-Islaman di media online memberikan kesempatan umat Islam untuk belajar memahami Islam dengan baik. Implikasinya adalah tumbuhnya semangat persatuan umat Islam yang sudah ditunjukkan melalui berbagai gerakan solidaritas baik secara virtual maupun empiris. Ketika masih tinggal di Bandar Lampung Rio melihat betapa jemaah masjid masih terkotak-kotak dalam aliran pemahaman, namun saat ini sudah berkurang. Demikian pula fenomena banyaknya kaum muslimah yang sadar menggunakan busana muslimah dengan hijab bahkan cadar. Hal ini menunjukkan bahwa kesadaran kaum muslim dan muslimah akan kewajiban dalam menjalankan apa yang ditetapkan syariat sudah semakin meningkat. Mudahnya mendapatkan informasi keagamaan dengan mengakses melalui media online menurutnya memberikan andil yang besar dalam meningkatkan kesadaran dan pengetahuan kaum muslimin untuk lebih memahami tentang Islam dan berbagai ketentuan hukumnya.

Persatuan umat Islam juga dapat dilihat dari kasus penistaan agama yang melibatkan Ahok. Hanya saja Rio tidak setuju dimanipulir kasus penistaan agama ini dimanipulir untuk kepentingan politik dan menyebabkan terjadinya ketegangan dan perpecahan dalam masyarakat khususnya yang menyangkut agama. Apalagi sampai menyerukan gerakan boikot terhadap sesama saudara muslim untuk tidak menguruskan jenazah atau mensholatkannya. Menurutnya ini termasuk tindakan radikal dan tentu tidak sesuai dengan apa yang diajarkan dalam Islam yang menekankan pada persatuan dan kewajiban muslim terhadap saudaranya.

Konten radikal sebagaimana banyak terdapat di dunia maya dipandangnya sebagai upaya untuk menyudutkan Islam di Indonesia agar tidak memiliki tempat bagi bersemainya nilai-nilai Islam. Ajaran Islam yang dipandang radikal dan melahirkan terorisme termasuk pondok-pondok pesantren dipandang sebagai tempat bersemainya sikap-sikap radikal yang mengarah pada terorisme merupakan bentukbentuk stigmatisasi yang tidak benar. Oleh karenanya Rio memilih untuk lebih banyak menambah ilmu dan pengetahuan agama dan bertanya pada ahlinya terkait dengan stigmatisasi Islam ini.

Rio juga berpandangan sama terkait dengan masalah khilafah, bahwa khilafah adalah bagian dari ajaran agama Islam dan merupakan sesuatu yang sudah dinubuatkan oleh nabi akan masa kedatangannya. Akan tetapi untuk penerapan khilafah saat ini, Rio tidak setuju karena belum masanya. Saat ini sistem yang dianut adalah sistem kenegaraan dengan Pancasila sebagai dasar negara dan NKRI sebagai bentuk negara masih dapat diterima sebagai sebuah pedoman hidup bersama. Karena betapapun sebagian aturan hukum dari NKRI diambil dari hukum Islam. Rio berharapan agar 
hukum Islam dapat ditegakkan di Indonesia meski menggunakan dasar falsafah Pancasila dan NKRI. Namun mengingat kenyataan yang ada seperti sekarang ini, hal tersebut akan sangat sulit untuk dilakukan. Oleh karenanya yang dapat dilakukan adalah menerima kondisi seperti saat ini sambil terus mempelajari dan mengevaluasi apa yang harus dilakukan. Secara konsisten terus menumbuhkan semggat belajar dan semangat dalam berdakwah untuk menegakkan hukum Islam di Indonesia.

\section{Simpulan}

Para informan merupakan generasi millenial yang akrab dengan lingkungan teknologi komunikasi dan informasi khususnya dengan media online, memiliki interaksi yang cukup intensif dan dapat menggunakannya secara positif dalam arti dapat membedakan antara realitas media dengan realitas empiris. Para informan juga menunjukkan sensitifitasnya terhadap konten yang dapat dimaknai sebagai konten radikal, dan mengkonfirmasinya dengan pengetahuan dan pengalaman yang dimiliki, serta mendiskusikannya dengan pihak-pihak yang dianggap lebih memiliki otoritas terkait dengan isu yang dibahas.

Kasus haram mengurus jenazah dan mensholatkan muslim yang mendukung Ahok dalam pilgub DKI, HTI yang ingin menggantikan sistem Pancasila dengan sistem khilafah, dan juga tindakan radikal ISIS dalam konteks negara Islam bertentangan dengan pengetahuan agama yang dimiliki informan. Mengurus jenazah merupakan kewajiban yang disyariatkan agama. Sedangkan kasus HTI dan ISIS terkait khilafah meski merupakan bagian dari ajaran Islam dan merupakan nubuat Nabi untuk masa akhir jaman nanti, para informan memandang HTI dan ISIS memanipulasi masalah khilafah ini untuk kepentingan politik mereka. Para informan memandang masalah khilafah adalah masalah nanti, saat ini adalah bagaimana hidup yang baik dan saling meghargai dalam bingkai Pancasila dan NKRI sambil terus meningkatkan pengetahuan dan pengamalan ajaran agama Islam dengan sebaik-baiknya. Sedangkan ideologi ISIS dipandang bukan merupakan representasi ideologi Islam yang rahmatan lil'alamin.

Kemampuan literasi dalam berinteraksi dengan media online dari para informan sedikit banyaknya dipengaruhi oleh internalisasi nilainilai yang diperolehnya baik dari lingkungan internal primer yakni keluarga yang terintegrasi dengan baik, dan lingkungan sosial sekunder yakni lingkungan tempat informan berinteraksi secara sosial baik di lingkungan tempat tinggal maupun lingkungan pendidikan yang menunjukkan sikap toleransi dalam keragaman dan perbedaan sehingga tidak mudah dipengaruhi oleh konten-konten yang bernuansa radikal.

\section{Daftar Pustaka}

al-Barry, M. Dahlan (1994). Kamus Ilmiah Populer. Surabaya: Penerbit Arkola. Baran, Stanley J., Davis Dennis K. (2015 ). Mass Communication Theory: Foundations, Ferment, and Future. $7^{\text {th }}$ edition. Stamford : Cengage Learning.

Daymon, Christine \& Holloway, Immy (2011).Qualitative Research Methods in Public Relations and Marketing Communications. $2^{\text {nd }}$ edition. New York : Routledge.

Dilegge, Dave and Bunker, Robert J. (2016). Global Radical Islamist Insurgency: AL QAEDA AND ISLAMIC STATE NETWORKSFOCUSVOLII:2012-2014.. Bloomington : Small Wars Foundation.

Emzir. (2008). Metodologi Penelitian Pendidikan Kuantitatif dan Kualitatif. Jakarta: Raja Grafindo Persada. Genzuk, Michel. (2005). A Synthesis of Ethnographic Research. http:// w w w - b c f. u s c.edu/ g e n z uk/ Ethnographic_Research.pdf diakses tanggal 18 Oktober 2016.

Hobbs, R. \& Frost, Richard. (2003). Measuring the Acquisition of Media Literacy Skill. Reading Research Quarterly Vol. 38, No. 3 July/August/ September 2003. International 
Reading Association (pp. 330-355). Laughlin, Paul Mc (2012). Radicalism: A Philosophical Study. New York : Palgrave Macmillan. Lipschultz, Jeremy Harris ( 2015). Social Media Communication: Concepts, Practices, Data, Law and Ethics. $2^{\text {nd }}$ edition. London : Routledge.

Linda Holtzman, Leon Sharpe (2014). Media Messages: What Film, Television, and Popular Music Teach Us About Race, Class Gender, and Sexual Orientation. 2 nd edition. New York : M.E. Sharpe.

Nazimb, Azyyati Mohd. (2017). Strategi Dakwah Islam Melalui Media Online NU. Proceedings ISLAC 2017: The Social Harmony Through Islamic Law. International Seminar on Islamic Jurisprudence in Contemporary Society $4^{\text {th }}-5^{\text {th }}$ March 2017. Faculty of Islamic Contampoprary Studies, UniSZA.

Potter, W, James. (2011), Media Literacy, $5^{\text {th }}$ edition. London, Sage Publication Inc.

Potter, W, James. (2010), The State of Media Literacy. Journal of Broadcasting \& ElectronicMedia54(4),2010,pp.675-696

Rubin,A.J. (Ed.) (1998). Media Literacy (Special Edition). The Journal of Communication, 48 (3/4).

Romli, Asep Syamsul M., (2012). Jurnalistik Online. Panduan Praktis Mengelola Media Online. Bandung: Nuansa Cendikia. Saputraa, Rahmat \& Romli, M \& Syamsul, Asep (2012). Jurnalistik Online : Panduan Praktis mengelola Media Online. Nuansa Cendikia : Bandung. Silverblatt, Art (1995). Media Literacy. Wesport and London : Praegar.

\section{Internet}

White, Jeremy (2012). Virtual Indoctrination and the Digihad: The Evolution of Al-Qaeda's Media Strategy. Small Wars Journal, 19 Nov 2012 dalam http://smallwarsjournal.com/jrnl/art/ virtual-indoctrination-and-the-digihad. diakses tanggal 28 Oktober 2017.

Yakin, Ainul (2015). Beda Radikal dan Radikalisme (1). https://www.hidayatullah.com/ artikel/ ghazwul-fikr/read/2015/09/01/77263/ beda-radikal-dan-radikalisme-1.html. Diakses tanggal 3 Oktober 2017.

Internet Top 20 Countries 2016. Internet World Stat dalam http://www. internetworldstats. com/ top20.htm. diakses tanggal 12 Oktober 2017.

Widiartanto, Yoga Hastyadi. 2016, Pengguna Internet di Indonesia Capai 132 Juta. Dalam http://tekno.kompas.com/ read/2016/10/24/15064727/2016.pengguna. internet.di.indonesia.capai.132.juta. diakses tanggal 15 Oktober 2017.

World's Most Literate Nations Ranked dalam http://webcapp. ccsu.edu/ di akses tanggal 15 Oktober 2016. 